\title{
त्री \\ Trajetórias e divisão do trabalho no laboratório de genética humana
}

\author{
Mariana Toledo Ferreira
}

\begin{abstract}
is
RESUMO

Este artigo discute a divisão do trabalho científico entre pesquisadores seniores e juniores em um centro de pesquisa brasileiro de genética humana e médica. Partindo do debate contemporâneo sobre a progressiva imbricação entre ciência e tecnologia - com progressiva fusão entre ambas, que evoca noções como a de tecnociência - é possível verificar, na subárea específica, velocidades crescentes na produção de dados, que pressionam os pesquisadores de maneiras distintas, seja pelo crescente custo das inovações tecnológicas, seja pela necessidade de métodos mais complexos para a análise. Nesse contexto, analiso questões relativas à especialização do trabalho científico, à separação entre concepção e execução, e às transformações correlatas na formação de novos pesquisadores. Parte-se do pressuposto teórico-metodológico de que a atividade científica não pode ser tratada de forma homogênea, existindo configurações distintas de acordo com o espaço disciplinar, a organização institucional e a tradição científica local, entendida enquanto empreendimento historicamente enraizado e social e culturalmente contingente.
\end{abstract}

Palavras- Ghave • Divisão do trabalho científico. Formação científica. Estudos de laboratório.

Genética humana. Genética médica. Tecnociência.

\section{INTRODUÇÃO}

O presente artigo discute o processo de formação de pesquisadores à luz da divisão e especialização do trabalho científico no interior de um laboratório brasileiro de genética humana e médica, em um contexto de investigação marcado pelo predomínio tecnológico da pesquisa e pelo ritmo crescente da produção de dados, que pressionam pesquisadores de maneiras distintas: pelo custo das inovações tecnológicas, pela necessidade de métodos mais complexos para a análise dos resultados e pela diversificação da formação dos jovens pesquisadores. O objetivo específico consiste em olhar para a maneira pela qual os jovens pesquisadores vêm sendo socializados no interior da disciplina de genética humana e médica, verificar que qualidades e habilidades eles consideram essenciais para tornarem-se bons profissionais, quais são suas concepções da profissão acadêmica e que identidades assumem no interior do laboratório. 
Os resultados apresentados fazem parte de pesquisa de mestrado (Ferreira, 2013), cujo objetivo foi analisar a maneira pela qual se dá a organização social da produção de conhecimento e da produção de produtores de conhecimento em uma disciplina específica - a genética humana e médica - em um país periférico, ainda que relativamente moderno, no que diz respeito às tradições centrais que dominam o desenvolvimento da ciência.

Através do estudo empírico de um centro de pesquisa localizado na Universidade de São Paulo (USP) foram observados indícios de mudanças na genética humana e médica a partir dos anos 1970 e, de forma mais acentuada, a partir dos anos 1990, no que diz respeito à presença da tecnologia definindo a atividade científica local, baseada no constante aprimoramento de instrumentos e técnicas. $\mathrm{O}$ aumento da complexidade ocorre em paralelo ao aumento no volume de produção de dados, decorrente do constante desenvolvimento das técnicas de sequenciamento, o que dificulta tanto seu acompanhamento quanto exige métodos de análise sempre mais complexos e refinados, incluindo conhecimentos avançados de estatística, computação e modelização, menos imprescindíveis em momentos anteriores. Essas mudanças de predomínio tecnológico, encontradas no centro de pesquisa, são correlatas aos desdobramentos que a pesquisa teve no cenário internacional e têm impacto significativo na divisão do trabalho no interior do laboratório, como se procurará mostrar.

O recorte em uma disciplina e em uma instituição particular está baseado no pressuposto, largamente partilhado por uma vertente contemporânea da sociologia da ciência (cf. Shinn \& Ragouet, 2008; Bourdieu, 2001a; Kreimer, 2010; Gingras, 1991), de que a atividade científica não pode ser tratada de maneira uniforme, existindo configurações distintas de acordo com a área de conhecimento, o espaço disciplinar, a organização institucional e a tradição científica à qual se filia, esta última entendida como empreendimento historicamente enraizado e social e culturalmente contingente. O eixo central consistiu na realização de uma pesquisa de campo detalhada e atenta à descrição de elementos pertinentes à atividade científica, suas instituições e práticas, em consonância com a recomendação de que, antes de fazer diagnósticos gerais sobre as transformações da ciência contemporânea, é necessário realizar estudos empíricos aprofundados para saber o que está, de fato, acontecendo nos diferentes espaços disciplinares (cf. Elzinga, 2002, p. 19).

Essa premissa teórico-metodológica torna-se ainda mais importante quando se leva em conta que as principais teorias sobre as transformações da ciência contemporânea que conseguem universalizar-se são elaboradas nos países centrais e, geralmente, a partir dos centros de pesquisa mais avançados. A título de exemplo, tem-se diagnósticos como o da emergência de uma cultura pós-acadêmica (cf. Ziman, 1990), de um futuro sem disciplinas científicas (cf. Gibbons et. al., 1994), de sistemas nacionais de 
inovação (cf. Nelson, 1993; Freeman, 1995), entre outros. No entanto, a compreensão do processo de transformação da atividade científica pressupõe a realização de pesquisas que privilegiem os contextos nacionais e a diversidade de instituições. Em outras palavras, trata-se de investigar os modos pelos quais as tendências globalizantes na produção científica e tecnológica geram heterogeneidade de resultados passíveis de serem observados empiricamente. Considera-se que, no processo de contextualização local das tendências globalizantes, elementos de diferentes níveis podem ligar-se de modos variados à tradição local de pesquisa, podendo tanto refrear como reforçar aspectos dessas tendências (cf. Garcia \& Carlotto, 2012, p. 127).

$\mathrm{O}$ artigo estrutura-se em quatro partes. A primeira seção discute as principais referências teóricas, enfatizando a noção de disciplina, a partir das contribuições de Pierre Bourdieu, Michel Foucault e Timothy Lenoir. A segunda seção apresenta a pesquisa de campo e fornece as características principais do centro de pesquisa estudado. Em seguida, busca-se contextualizar a discussão sobre a divisão do trabalho científico e a produção de produtores de conhecimento no debate contemporâneo sobre a tecnociência, devido principalmente à percepção de uma progressiva imbricação, na genética, entre ciência e tecnologia, com progressivo predomínio da segunda. Consequentemente, intenta-se descrever a transformação da pesquisa em genética humana e como o centro de pesquisa lidou com elas, a partir da análise da literatura sobre o tema e do depoimento de seus principais integrantes. Por fim, analisa-se com maior detalhe a divisão do trabalho no interior do centro, bem como os processos de formação dos jovens pesquisadores, destacando, na conclusão, os principais achados que necessitam de posterior aprofundamento.

\section{FormaÇÃo DE PESQUiSAdores No INTERIOR DE UMA DISGIPLINA}

O locus do processo de formação dos jovens pesquisadores é a disciplina; ela emerge como espaço crucial pois, assim como laboratórios e espaços de aprendizagem são essenciais para organizar e reforçar o conjunto de habilidades necessárias para conduzir a ciência localmente, as disciplinas são as estruturas em que essas habilidades são reunidas e reproduzidas como conjuntos coerentes, apropriados para a condução de uma prática científica globalmente mais estável (cf. Lenoir, 2003, p. 65). As disciplinas são a infraestrutura da ciência corporificada nos departamentos universitários, nos cursos de graduação e pós-graduação, nas sociedades profissionais, nos manuais e livros didáticos; são elas que formam a identidade de um pesquisador, estabelecendo problemas e definindo ferramentas para abordá-los. 
Ao mesmo tempo, disciplinas são instrumentos para distribuir status, estabelecer limites e demarcar hierarquias entre especialistas e amadores. Além disso, como tanto Foucault quanto Bourdieu insistiram, olhar para as disciplinas não é simplesmente analisar as instituições e a profissionalização do trabalho científico; é, acima de tudo, uma preocupação com os corpos humanos (cf. Lenoir, 2003, p. 65). Disciplinas são formações institucionalizadas para organizar esquemas de percepção, apreciação e ação, bem como para inculcá-los como ferramentas de cognição e comunicação (cf. Bourdieu, 2000, p. 256-85).

Aqui, é crucial a formulação de Foucault de que cada sociedade está baseada em um regime de verdade; a relevância do autor para a discussão do conteúdo de verdade do conhecimento disciplinar e da relação do conhecimento disciplinar com o sistema das relações de poder reside em sua insistência de que o poder deve estar nela baseado (cf. Foucault, 1980, p. 109-33). Por "regime de verdade", Foucault (1988, p. 11-4) tem em mente o corpo de práticas e os tipos de discurso que uma sociedade aceita e faz funcionar como verdadeiros; os mecanismos e instâncias que permitem a alguém distinguir afirmações verdadeiras e falsas e os meios pelos quais cada uma delas é sancionada; as técnicas e procedimentos a que se dá valor na aquisição de verdade; e o estatuto daqueles que são encarregados de dizer o que conta como verdade. É central, para essa concepção da relação do poder com o conhecimento, a noção de que esse poder não é uma força negativa e repressiva que pesa sobre todos, mas uma rede produtiva que atravessa todo o corpo social (cf. Foucault, 1979, p. 88-97).

É com esse sentido de controle, não como algo externo ou repressivo mas, antes, por meio da incorporação de padrões de discurso, de estruturas de conhecimento e de modalidades de prática, que é possível relacionar a presente discussão da disciplina científica. Desse ponto de partida, as disciplinas podem ser consideradas estruturas essenciais para sistematizar, organizar e incorporar as práticas sociais e institucionais das quais dependem tanto o discurso coerente quanto o exercício legítimo do poder (cf. Lenoir, 2003, p. 67). São essas mesmas práticas que precisam ser incorporadas pelos novos integrantes das disciplinas.

Mas, ao mesmo tempo, a abordagem arqueológica de Foucault não ilumina a formação das disciplinas, embora ajude a conceituá-las. A consideração das disciplinas como mediadoras para a prática científica (cf. Lenoir, 2003, p. 7०-3) sugere um caminho alternativo. Seguindo Bourdieu, é possível associar as disciplinas ao conceito de campo científico, concebendo as disciplinas como lugares de competição pelo monopólio da autoridade científica, que é inseparavelmente definida como capacidade técnica e poder social (cf. Gingras, 1991, p. 5).

Com a noção de campo científico, Bourdieu (2001a, p. 110-23) quer romper a falsa oposição entre análise interna e análise externa da ciência, afirmando que não há 
"escolha" científica - do campo da pesquisa, dos métodos utilizados, do lugar de publicação, ou ainda, escolha entre uma publicação imediata de resultados parcialmente verificados e uma publicação tardia de resultados plenamente controlados " que não seja uma estratégia de investimento orientada para a maximização do lucro propriamente científico, isto é, para a obtenção do reconhecimento dos pares concorrentes.

O campo científico de Bourdieu (2001a) tem uma lógica própria e uma forma específica de capital. O campo não é apenas um domínio de posições intelectuais diferencialmente construídas; ele inclui, também, instrumentos de circulação, como jornais e editoras, instituições preocupadas em consagrar bons trabalhos mediante a outorga de prêmios e admissões em academias, e instituições responsáveis pela circulação e reprodução de outros participantes, a saber, as instituições educacionais. No caso das ciências naturais, um meio adicional de circulação é a produção de instrumentos científicos, incluindo sua padronização e venda para outros pesquisadores (Lenoir, 2003, p. 27-8).

Cada campo, até os mais "puros", como o campo artístico ou o científico, tem um ponto de vista constitutivo que precisa ser aceito tacitamente por seus membros, e que define o pensável e o impensável, matriz de todas as questões pertinentes. Cada campo define, assim, o que vale a pena se interessar - ou disputar -, algo que pode não fazer sentido para aqueles que se situam no seu exterior (cf. Bourdieu, 2001b, p. 117-24). Em outras palavras, cada campo possui sua doxa específica, conjunto de pressupostos cognitivos e avaliativos, o que permite a existência de adversários cúmplices, que, ocupando polos opostos, estão de acordo e reconhecem o que os opõe, delimitando, assim, o espaço legítimo da discussão (cf. Bourdieu, 2001b, p. 117-24).

Esses pressupostos aparecem como que inscritos na natureza das coisas e exigem uma adesão tácita, uma forma particular de crença, a illusio, condição indiscutida da discussão em um campo (cf. Bourdieu, 2001b, p. 117-24). Essa adesão tácita acontece, no caso do campo científico, a partir de um longo processo de socialização em determinada disciplina. Para que esse jogo aconteça, Gingras (1991, p. 5) afirma que recursos materiais e instituições precisam estar disponíveis, para que os agentes possam produzir o conhecimento que circula no campo. É ao colocar em prática estruturas institucionais que favorecem a produção do conhecimento e a reprodução dos agentes portadores das disposições necessárias, que os cientistas são capazes de se reproduzir enquanto grupo.

Considerando que a atividade de pesquisa é realizada por agentes sociais com características particulares, sua descrição supõe explicar a produção desse tipo de agente e sua relação com o campo científico. O processo de socialização dos cientistas tende a produzir pessoas que estão tão comprometidas com os valores centrais de sua disciplina que os aceitam sem pensar; a atividade de pesquisa aparece como "natural". 
Esse comprometimento é o resultado de um prolongado processo de treinamento, que será esquadrinhado a partir de dados referentes a um centro de pesquisa em genética humana e médica da USP.

\section{Sobre o EStudo de cAso}

O centro de pesquisa estudado foi criado em 2000 , a partir da justaposição de laboratórios de genética humana e médica previamente existentes na USP, e desenvolve pesquisa básica e aplicada, atividades ligadas à educação e à transferência de tecnologia, além de fornecer serviço de aconselhamento genético. Oficialmente é composto por sete laboratórios, cada um chefiado por uma pesquisadora sênior, professora da USP. ${ }^{1}$

Ele é um dos onze Centros de Pesquisa, Inovação e Difusão (Cepid) da Fundação de Amparo à Pesquisa do Estado de São Paulo (Fapesp), programa inspirado no modelo norte-americano de centros de ciência e tecnologia da National Science Foundation, e tem como objetivo, segundo Fernando Perez, diretor científico da Fapesp quando do lançamento do programa,

estabelecer um novo paradigma para a pesquisa científica. O maior desafio da política científica e tecnológica, que é o desafio dos Centros, é propor uma visão integrada da atividade de pesquisa com a transferência de conhecimento para o setor público e privado e a educação (Fapesp, 2000, p. 12).

Nesse sentido, o objetivo do programa é selecionar grupos que realizam pesquisa de ponta, de caráter multidisciplinar, que possam subsidiar políticas públicas ou contribuir para a criação de novas tecnologias. O centro recebe financiamento também do Programa Institutos Nacionais de Ciência e Tecnologia, do Conselho Nacional de Desenvolvimento Científico e Tecnológico (CNPq), que tem como objetivo estimular o desenvolvimento de pesquisa científica e tecnológica, associada a aplicações, para promover a inovação em áreas prioritárias para o desenvolvimento regional e nacional. Por fim, recebe verbas da Financiadora de Estudos e Projetos (Finep), a partir do edital de criação de Centros de Terapia Celular, que tem como objetivo desenvolver técnicas de cultivo de células-tronco humanas e qualificar equipes para os laboratórios brasileiros públicos e privados.

1 Todos os laboratórios são coordenados por pesquisadoras seniores, sendo a presença feminina um elemento notável que, embora não explorado aqui, faz parte dos desdobramentos futuros desta pesquisa. 
Com base nessa breve descrição, é possível notar que o centro estudado é reconhecido e legitimado em seu âmbito de atuação, conjugando verbas das três maiores agências brasileiras de fomento à pesquisa. Essa é uma das razões que fazem dele um “caso exemplar", apresentado para a comunidade científica como um modelo a ser seguido por outras instituições. Procedimento de escolha semelhante é feito por Shinn e Marcovich (2009, p. 11-2), que estudaram os ganhadores do Prêmio Feynman de Nanotecnologia para poder identificar e discutir o que é considerado, entre os praticantes da pesquisa em nanoescala, como pesquisa de ponta e investigação promissora, ou seja, o que é visto como modelar e digno de recompensa. Nessa pesquisa, o suporte financeiro ao centro de pesquisa é considerado como indicador de legitimidade semelhante a uma premiação, que reconhece o valor do que foi realizado e incentiva novas realizações.

As duas principais linhas de pesquisas do centro são:

(1) definir os fatores genéticos responsáveis por doenças em seres humanos, incluindo a identificação de genes responsáveis por doenças genéticas, estudos cromossômicos, estudo de doenças complexas e variação genética da população;

(2) desenvolver abordagens terapêuticas para doenças genéticas, incluindo o estudo do potencial regenerativo das células-tronco de diferentes origens e abordagens farmacológicas.

Além da pesquisa, o centro presta diversos serviços, seguindo os moldes propostos pelo programa Cepid, destacando-se entre eles os testes e aconselhamento genéticos. Para além desses serviços de extensão no sentido mais clássico, de aplicação de conhecimento para a prestação de serviços especializados à população externa à universidade, o centro de pesquisa realiza também serviço de sequenciamento de DNA para outros pesquisadores que não tenham acesso a essa tecnologia, mediante pagamento.

Para tanto, conta com uma equipe de aproximadamente 90 pessoas, entre professores, pesquisadores, médicos e técnicos especializados, além de estudantes de graduação e pós-graduação. Oficialmente são doze os pesquisadores seniores vinculados ao centro, sendo sete as pesquisadoras mais atuantes, cada uma delas com laboratório próprio. Apesar de oficialmente ser um centro de pesquisa, sua descrição mais precisa seria a de um conglomerado de laboratórios, previamente existentes, que se juntaram em busca de maior financiamento e melhor estrutura para pesquisa.

Foram contatadas para esta pesquisa as coordenadoras dos sete laboratórios bem como jovens pesquisadores de cada grupo, totalizando 28 entrevistas, realizadas em 
2013. Inspirando-se no trabalho de Terry Shinn (1988, p. 5), os entrevistados foram divididos nas categorias de pesquisadores seniores e pesquisadores juniores, devido às características que partilham: tem-se como seniores as sete pesquisadoras que coordenam os laboratórios e como juniores (ou jovens pesquisadores) aqueles que realizam sua formação em um desses laboratórios. Essa distinção não se refere a uma idade biológica, mas a certo status no interior da carreira acadêmica, com características compartilhadas que serão delimitadas mais à frente.

Este artigo centra-se nas 21 entrevistas aprofundadas e semiestruturadas realizadas com jovens pesquisadores em genética humana e médica, cuja trajetória se localizava entre o doutorado e o pós-doutorado. Os principais temas tratados foram o cotidiano de trabalho; a formação e processo de aprendizagem de novas técnicas e métodos de pesquisa; as motivações e horizontes de carreira profissional. ${ }^{2}$

A quantidade restrita de entrevistas realizadas não permite fazer generalizações sobre a formação atual do geneticista humano no Brasil, mas serão delineados alguns elementos que podem, posteriormente, ser objeto de estudo mais aprofundado. É importante destacar, ainda, que o centro não foi tomado nesta pesquisa nem como caso exemplar - que poderia ser usado, por exemplo, para subsidiar políticas públicas para a ciência - nem como caso representativo médio - passível de generalizações apressadas -, mas sim como um caso que permite a análise pormenorizada das questões apresentadas. $O$ estudo situado dessa maneira permite contribuir para a teoria sociológica pondo à prova generalizações anteriores, estabelecendo novos desafios interpretativos e sugerindo novas questões de pesquisa.

\section{Giêngia, teGnologia e teGnoGiênGia:}

\section{A DIVISÃO DO TRABALHO GIENTÍFICO EM UM CONTEXTO EM TRANSFORMAÇÃO}

No âmbito da sociologia, da filosofia e dos estudos sociais da ciência, há um debate sobre as mudanças recentes na relação entre a ciência e a tecnologia e a emergência da tecnociência. Existe pouco consenso entre os pesquisadores sobre o que seria a tecnociência e muitos dos usos desse termo carecem de fundamentação teóricometodológica.

Para Marcovich e Shinn (2012), tecnociência não existiria enquanto atividade de pesquisa distinta e específica, atividade essa em que as fronteiras entre as disciplinas

\footnotetext{
2 Menos exploradas neste artigo, as entrevistas com as pesquisadoras seniores buscavam delimitar suas trajetórias acadêmico-profissionais e seu processo de formação, bem como elementos para retraçar o processo de institucionalização da pesquisa em genética humana e as suas mudanças a partir dos anos 1970 .
} 
não seriam respeitadas. Ao contrário, existiriam regimes de produção científicos e tecnológicos, altamente diferenciados e especializados. Os autores propõem uma visão pluralista de ciência e tecnologia que incorpora múltiplos regimes historicamente estabelecidos de produção e difusão de conhecimentos, e que permite especificar seus numerosos desenvolvimentos históricos, modos de produção, mercados de difusão, sem ser necessário fazer uso do conceito de tecnociência (cf. Marcovich \& Shinn, 2012, p. 36-59). Para os autores, o nascimento do modelo da tecnociência, que obteve considerável sucesso recentemente, pode ter derivado de uma má interpretação de experiências históricas e atuais em ciência e tecnologia, onde não foram devidamente levados em conta estruturas, como as disciplinas, e dinâmicas, como a circulação (cf. Marcovich \& Shinn, 2012, p. 51-2).

Hugh Lacey (2012, p. 104-6) considera "tecnociência" um termo descritivo, não muito teórico, nem muito preciso. Ainda assim, defende sua utilização, em um contexto em que forças sociais, econômicas e políticas enfatizam o valor da tecnociência, em detrimento de formas distintas de produção de conhecimentos. $\mathrm{O}$ autor mostra que essas forças levam a tecnociência a deslocar outras formas do fazer científico, de modo que a ciência - enquanto fenômeno social - torna-se efetivamente identificada com a tecnociência. A tecnociência seria um tipo de atividade caracterizada pela pesquisa a partir de estratégias descontextualizadas (principalmente no laboratório), e pelo uso de tecnologia avançada para a produção de instrumentos, objetos experimentais, novos materiais (cf. Lacey, 2012, p. 114-6).

Nesse sentido, a tecnociência pode fazer parte da ciência cujo objetivo é obter conhecimento em novas áreas, especialmente a compreensão de novas possibilidades para o desenvolvimento de produtos, como aqueles ligados à indústria química ou farmacêutica. Ou seja, conhecimento que leva à inovação, guiado por valores de mercado, como crescimento econômico e desenvolvimento de vantagens competitivas (cf. Lacey, 2012 , p. 115). Lacey não reduz a ciência à tecnociência, nem nega que exista um deslocamento na interação dinâmica entre ambas, mas destaca a onipresença da tecnologia em diversos aspectos das pesquisas científicas, onipresença tamanha que parece arbitrário tentar distinguir o que é ciência do que é tecnologia (cf. Lacey, 2012, p. 104).

Com base nas ideias de Lacey e de Shinn e Marcovich, e seguindo a premissa apresentada na introdução - da necessidade de realização de pesquisas em contextos locais e institucionais específicos -, defende-se neste artigo que uma ruptura epistemológica ocasionada pela tecnociência deve ser tratada como hipótese que necessita de maior investigação e não deve ser tomada como um dado da realidade. Simultaneamente, partindo dessas breves considerações sobre a ciência e a tecnociência, aparece como inegável a presença constante da tecnologia nas pesquisas científicas, algo que foi constatado neste estudo em um centro de pesquisa que, com o progressivo desen- 
volvimento da automação e instrumentação, teve que lidar e desenvolver novas dinâmicas de divisão do trabalho e de produção de conhecimento.

A seguir, busca-se discutir brevemente as principais transformações na pesquisa em genética humana e médica e de que maneira elas foram incorporadas no centro de pesquisa analisado, para mostrar a progressiva modificação não apenas das questões de pesquisa, como das técnicas, instrumentos e demais práticas, principalmente a partir da crescente incorporação da biologia molecular no estudo do humano e da passagem da genética clássica para a "nova genética" ou genômica. ${ }^{3}$

De maneira esquemática é possível definir a genética clássica e a genômica da seguinte maneira: a genética mendeliana ou clássica é aquela que estuda a correlação entre um único gene e um traço (cor dos olhos, por exemplo) ou uma doença (monogênica); entre os humanos, esse conhecimento segue a análise do padrão familiar de repetição; a genômica, por sua vez, é o estudo direto de genes, de suas funções e interações. Além das doenças monogênicas, ela foca em doenças poligênicas, envolvendo a interação entre diferentes genes e destes com fatores ambientais.

O marco mais emblemático dessa "nova genética" é, sem dúvida, o Projeto Genoma Humano (PGH). As pesquisas em ciências humanas sobre o tema têm explorado o desenvolvimento de técnicas laboratoriais (cf. Rabinow, 1996), o desenvolvimento de técnicas de mapeamento, computação e automação dos processos (cf. Mackenzie, 2003), as modificações na prática clínica (cf. Lock, 2008), além das implicações éticas de tal empreendimento (cf. Dreger, 2000). De forma resumida, é possível afirmar que o PGH foi um megaprojeto que associou desenvolvimentos da pesquisa em genética, biologia molecular, biofísica, teoria da informação e computação, marcando a conversão da pesquisa biológica a um modelo predominantemente molecular.

A biologia molecular desenvolveu-se ao longo do século xx e apresenta como marcos relevantes o descobrimento da estrutura de DNA (1953), das técnicas de RNA recombinante (1970) e de novas técnicas e equipamentos que automatizaram o processo de sequenciamento (1995). De início, a biologia molecular concentrou-se no estudo de micróbios, vírus, bactérias, organismos mais simples e, a partir deles, desenvolveu uma série de técnicas que puderam ser, posteriormente, utilizadas na genética humana (cf. Rheinberger, 2000, p. 24-5). Foi a partir de 1970 que o desenvolvimento técnico permitiu de forma mais consistente a migração da pesquisa para os humanos, com destaque para o desenvolvimento da eletroforese em gel, e da hibridização in situ (cf. Wilkie, 1994, p. 71-81). ${ }^{4}$ Outro marco fundamental deu-se em 1977 ,

3 A expressão "nova genética” foi cunhada em 1980 por David Comings, editor da revista American Journal of Human Genetics, ao comentar as novas técnicas para análise do DNA (cf. Wilkie, 1994, p. 115).

4. A eletroforese em gel auxilia na separação de moléculas - geralmente proteínas e moléculas de DNA e RNA e envolve a migração de partículas em um determinado gel durante a aplicação de uma diferença de potencial; 
quando Fred Sanger, na Inglaterra, e Walter Gilbert e Alan Maxam, nos Estados Unidos, desenvolveram independentemente métodos para a leitura rápida da sequência de pares de bases em qualquer trecho do DNA. Em meados da década de 1980, tornouse disponível uma nova técnica que permitiu produzir bilhões de cópias de um único fragmento de DNA e que estava baseada na chamada reação em cadeia da polimerase (PCR) (cf. Rabinow, 1996, p. 1-17).5 Um dos primeiros triunfos da introdução das técnicas da biologia molecular em genética humana ocorreu em 1986, quando Tony Monaco, do Hospital para Crianças de Boston, e Louis Kunkel, da Universidade de Harvard, identificaram o defeito genético responsável pela distrofia muscular Duchenne (cf. Wilkie, 1994, p. 35-40).

A noção de uma ciência em nível molecular varia consideravelmente conforme os agentes que a empregam, sendo considerada por alguns como uma disciplina científica com status cognitivo autônomo (cf. Abir-Am, 1982, p. 344-53; Kay, 1993, p. 3-21) e por outros como um potente conjunto de técnicas para a compreensão de fenômenos complexos em toda sorte de organismos (cf. Sloan, 2000, p. 8-10). Seja como for, essa forma de prática científica passou a dominar institucional e conceitualmente os departamentos de biologia em grande parte do mundo ocidental após os anos 1960 e foi paulatinamente estendida, a partir da década de 1970, para a genética humana.

No final da década de 1990, o sequenciamento em larga escala do genoma teve considerável impulso devido à ampliação da automação do processo e, também, ao avanço da tecnologia computacional de análise de sequências de DNA (cf. Baltimore, 2001, p. 814). É nesse sentido que afirma-se que o desenvolvimento da pesquisa molecular é marcado pelo uso intensivo de aparatos tecnológicos e informacionais, com uma transformação contínua de suas bases tecnológicas (cf. Silva \& da Costa, 2012, p. 496).

Internacionalmente, o campo da genômica ganha destaque a partir dos anos 1970, sobretudo pelos avanços dos projetos de sequenciamento genético de uma diversidade de organismos. Essa nova forma de fazer pesquisa reconfigurou os rumos das pesquisas, definindo áreas prioritárias para a formulação de programas e para a destinação de recursos financeiros (cf. Silva \& da Costa, 2012, p. 494). No Brasil, é a partir da década de 1990 que há um aumento considerável no incentivo e financia-

as moléculas são separadas de acordo com o seu tamanho, pois as de menor massa irão migrar mais rapidamente que as de maior massa. Por sua vez, a hibridização in situ auxilia os cientistas a identificar diretamente a localização de um gene, a partir da deteç̧ão de pequenos segmentos de DNA ou RNA a partir de "sondas" específicas, que são sequências de nucleotídeos complementares desenvolvidas a partir de segmentos conhecidos do DNA ou RNA que se deseja identificar.

5 O PCR é uma das técnicas mais utilizadas em laboratórios de pesquisas médicas e biológicas para diversas tarefas, como o sequenciamento de genes e diagnóstico de doenças hereditárias e a identificação de "impressão digital" genética (usado em testes de paternidade e na medicina forense). Trata-se de um método de amplificação de DNA sem o uso de um organismo vivo, como bactérias ou leveduras. 
mento, com a primeira iniciativa partindo da Fapesp, que adotou como um de seus objetivos institucionais a criação dessa nova subárea de pesquisa (cf. Dal Poz, 2002, p. 23-9). Para isso, foi formulado o primeiro projeto genoma brasileiro, ${ }^{6}$ possuindo três metas: formar grande número de pesquisadores, participar da comunidade genômica internacional, e estimular a incorporação da biotecnologia no setor produtivo (cf. Henriques, 2010, p. 100-2). A partir de então, constituiu-se uma orientação de política científica e tecnológica no estado de São Paulo (e depois no resto do país), voltada ao desenvolvimento de uma infraestrutura que estimulasse esse tipo de pesquisa.

Do ponto de vista do centro analisado, é possível verificar essas transformações a partir da pesquisa em distrofias musculares, uma das doenças estudadas de forma mais duradoura, desde os estudos de pós-graduação da coordenadora da instituição, na década de 1970. Antes da descoberta da localização do gene da distrofia muscular de Duchenne, só era possível identificar os portadores da doença com base na dosagem da enzima creatino - quinase. Uma das pesquisadoras seniores relata o efeito que a descoberta do gene teve em sua pesquisa de doutorado.

Enquanto estava terminando meu doutorado em um tema, vamos dizer, um pouco antigo, de estudos de enzimas no músculo, foi descoberto o gene da distrofia de Duchenne. Então mudou radicalmente toda a maneira de se fazer pesquisa. De repente. Porque passamos para ferramentas moleculares, você vai direto no gene, se achar a alteração você vai direto na mãe do paciente para ver se ela é portadora (pesquisadora sênior 3).

Os artigos publicados até o final da década de 1980 analisavam o paciente sob o ponto de vista de suas condições físicas, por sexo ou etnia, dos sintomas e das estatísticas da doença na população. A partir da década de 1990, a análise pela biologia molecular tornou-se preponderante e, de 2000 em diante, as pesquisas com células-tronco, combinadas com as ferramentas da biologia molecular, passaram a ocupar espaço quase hegemônico na agenda de pesquisa do centro. Nesses três períodos, os problemas de pesquisa elaborados pelas pesquisadoras relacionaram-se às ferramentas de análise disponíveis (cf. Osada, 2012, p. 14,2-7).

A transição para a análise molecular dependeu, em grande medida, da capacitação dos pesquisadores em laboratórios na Europa e EUA, e teve início com a ida de uma pesquisadora à Inglaterra, quando de seu pós-doutorado, em 1988. A transição também foi fortalecida pela participação de duas pesquisadoras seniores no Projeto

60 Projeto Genoma Fapesp consistiu no sequenciamento da bactéria Xylella Fastidiosa, causadora da praga do amarelinho nas plantações de laranja, afetando, assim, um importante produto do agronegócio paulista. 


\section{TABELA 1}

\begin{tabular}{|c|c|c|c|c|}
\hline & \multirow[t]{2}{*}{ Genética clássica } & \multicolumn{2}{|l|}{ Biologia Molecular } & \multirow[b]{2}{*}{ Células-tronco } \\
\hline & & $\begin{array}{l}\text { Pré-Projeto } \\
\text { Genoma Fapesp }\end{array}$ & $\begin{array}{l}\text { Projeto Genoma } \\
\text { Fapesp }\end{array}$ & \\
\hline Período & $197^{1-1989}$ & $1990-2000$ & $2001-2004$ & $2005^{-2011}$ \\
\hline Número de artigos & 42 & 143 & 88 & 99 \\
\hline \multirow{6}{*}{$\begin{array}{l}\text { Principais temas } \\
\text { de pesquisa publi- } \\
\text { cados em artigos }\end{array}$} & $\begin{array}{l}\text { Quadro clínico } \\
\text { geral sobre a dis- } \\
\text { trofia muscular } \\
\text { (MD) } 57^{\%}\end{array}$ & $\begin{array}{l}\text { Técnicas da biolo- } \\
\text { gia molecular, es- } \\
\text { tudos sobre tre- } \\
\text { chos de DNAs 53\% }\end{array}$ & \multirow{2}{*}{$\begin{array}{l}\text { Técnicas da biolo- } \\
\text { gia molecular, es- } \\
\text { tudos sobre tre- } \\
\text { chos de DNA } 65 \%\end{array}$} & $\begin{array}{l}\text { Técnicas da biolo- } \\
\text { gia molecular, es- } \\
\text { tudos sobre tre- } \\
\text { chos de DNA } 4,0 \%\end{array}$ \\
\hline & Enzimas $23 \%$ & Enzimas $5 \%$ & & $\begin{array}{l}\text { Novas doenças e } \\
\text { novos genes 8\% }\end{array}$ \\
\hline & $\begin{array}{l}\text { Aconselhamento } \\
\text { genético } 9 \%\end{array}$ & $\begin{array}{l}\text { Aconselhamento } \\
\text { genético } 15 \%\end{array}$ & \multirow{2}{*}{$\begin{array}{l}\text { Novas doenças e } \\
\text { novos genes } 15 \%\end{array}$} & $\begin{array}{l}\text { Discussão de no- } \\
\text { vas tecnologias na } \\
\text { genética } 8 \%\end{array}$ \\
\hline & $\begin{array}{l}\text { Pesquisas relacio- } \\
\text { nando etnia } 12 \%\end{array}$ & $\begin{array}{l}\text { Quadro clínico ge- } \\
\text { ral da doença 10\% }\end{array}$ & & \multirow{3}{*}{$\begin{array}{l}\text { Terapias: células- } \\
\text { tronco } 40 \%\end{array}$} \\
\hline & $\begin{array}{l}\text { Pesquisas relacio- } \\
\text { nando sexo 18\% }\end{array}$ & $\begin{array}{l}\text { Pesquisas relacio- } \\
\text { nando sexo } \eta^{\%}\end{array}$ & \multirow{2}{*}{$\begin{array}{l}\text { Estudos sobre } \\
\text { Alzheimer, obesi- } \\
\text { dade, distúrbio } \\
\text { bipolar, esquizo- } \\
\text { frenia } 15 \%\end{array}$} & \\
\hline & $\begin{array}{l}\text { Terapia: inibição } \\
\text { do hormônio do } \\
\text { crescimento } 19 \%\end{array}$ & $\begin{array}{l}\text { Terapia: este- } \\
\text { roides } 3 \%\end{array}$ & & \\
\hline \multirow[t]{2}{*}{ Total } & Outros 3\% & Outros $7 \%$ & Outros $5 \%$ & Outros $4 \%$ \\
\hline & $100 \%$ & $100 \%$ & $100 \%$ & $100 \%$ \\
\hline
\end{tabular}

Genoma Fapesp. As mudanças ocorreram de forma relativamente rápida, sendo que um laboratório de biologia molecular foi montado quando do retorno da pesquisadora:

Acho que a gente deu realmente um grande passo fazendo isso, porque a defasagem entre Brasil e exterior era enorme. E acho que isso realmente causou uma pequena revolução tecnológica aqui, porque permitiu começar a responder um monte de novas perguntas (pesquisadora sênior 2). 
A partir de entrevistas com pesquisadoras do centro, é possível detectar três tipos de idas a outros centros de pesquisa: (1) para o aprendizado de técnicas ainda não disponíveis no laboratório; (2) para realizar com maior rapidez procedimentos que ainda não foram bem estabelecidos; e (3) para entrar em contato com outros trabalhos e pesquisadores e estabelecer colaborações científicas. A ida para o aprendizado de novas técnicas é talvez a experiência mais comum entre os pesquisadores, no início de suas carreiras científicas: "fui para o Canadá, fiquei lá um mês, para aprender técnica de western blot, que ainda não se conseguia fazer direito aqui e eu trouxe essa metodologia" (pesquisadora sênior 1). A economia de tempo também foi considerada importante para as duas gerações de pesquisadores: "eu passei um mês e meio na Universidade de Iowa. Fui para ficar três, mas tudo lá funcionava muito bem, então acabei voltando antes" (pesquisadora júnior 1).

Apesar de ser de mais curta duração e geralmente mais especializada, a ida ao exterior continua sendo fundamental para a atualização das pesquisas no centro, em um contexto em que as técnicas da pesquisa em genética mudam rapidamente, incentivadas tanto pelo andamento das pesquisas científicas acadêmicas quanto pelo estabelecimento de empresas que realizam pesquisa, bem como de empresas voltadas exclusivamente para o desenvolvimento de equipamentos e reagentes. O surgimento de empresas de biotecnologia (cf. Garcia \& Martins, 2009, p. 84-8) voltadas ao desenvolvimento de produtos e serviços como medicamentos e exames diagnósticos, como a Celera e a 23 andMe, e de empresas de pesquisa clínica, associadas à indústria farmacêutica, marcam a pesquisa em genômica (cf. Osada, 2012, p. 34).

Como essas transformações não ocorrem a partir do Brasil, mas a partir dos grandes centros de pesquisa estadunidenses e europeus, a busca para manter-se atualizado nunca se encerra. O estágio atual das pesquisas se caracteriza pela elevação dos custos de organização e manutenção da infraestrutura de pesquisa, ao qual o grupo de cientistas estudado tenta fazer frente mediante a articulação de recursos provenientes de diversas fontes. Em paralelo, há um aumento considerável da complexidade e das exigências, não só em termos de habilidades de gestão, mas também no que diz respeito ao estilo de pesquisa, manipulação de equipamentos e incorporação de novas técnicas, além de novos modos de financiamento. É possível verificar, então, que a produção de conhecimento científico foi impactada a partir da introdução de técnicas da biologia molecular, dos esforços de pesquisadores em adaptar seus laboratórios e na formação, e dos vultuosos investimentos em projetos genoma por parte das agências de fomento à pesquisa científica.

Uma característica comum a todos os laboratórios que compõem o centro de pesquisa é que a atualização nas novas técnicas e instrumentos foi realizada pelos pesquisadores mais novos, durante o doutorado e/ou o pós-doutorado, e não pelos pesquisa- 
dores seniores. Esse padrão é seguido também atualmente, pois as pesquisadoras juniores dos anos 1980 e início dos anos 1990, que são agora coordenadoras de seus próprios laboratórios, deixam a cargo de seus orientandos a continuidade do processo. Tal constatação é fundamental para compreender, em maiores detalhes, a divisão do trabalho e a formação de novos pesquisadores.

\section{A PRODUÇÃo DE PRODUTORES DE GONHEGIMENTO}

O processo de formação é uma dimensão central no estudo sociológico da ciência (cf. Ben-David, 1974; Bourdieu, 2001a), pois é quando os cientistas incorporam a tradição científica (e a tradição local) de seu domínio de pesquisa. É nessa socialização na ciência que os indivíduos entrarão em contato com uma tradição profissional de teorias, técnicas e habilidades. Na disciplina de genética humana, as credenciais para a inserção no campo estão definidas, no mínimo, pelo doutorado, mas, devido ao crescimento quantitativo da formação de doutores no país, à escassa disponibilidade de postos na carreira acadêmica e à consequente competição, o pós-doutorado aparece progressivamente como etapa igualmente fundamental.

A tabela abaixo resume os principais dados sobre a formação dos jovens pesquisadores entrevistados.

TABELA 2

$\begin{array}{lccccc} & \text { Graduação Ciências biológicas } & \text { Na USP } & \text { Iniciação científica } & \text { Mestrado Experiênciainternacional } \\ \text { Sim } & 16 & 12 & 20 & 11 & 12 \\ \text { Não } & 5 & 9 & 1 & 10 & 21 \\ \text { Total } & 21 & 21 & 21 & 21\end{array}$

A tabela indica que a maior parte dos jovens pesquisadores entrevistados cursou ciências biológicas na graduação, sendo outros cursos presentes o de biomedicina, por dois juniores, e o de ciências moleculares, farmácia e odontologia, cada um atendido por um jovem pesquisador. Outra característica é que uma parte deles não realizou a graduação na USP, tendo frequentado outras universidades como a Universidade Federal do Rio Grande do Sul (UFRGS), a Universidade Federal do Pernambuco (UFPE), a Universidade Federal do Paraná (UFPR), a Universidade Estadual de Campinas (Unicamp), a Universidade do Estado de São Paulo (Unesp) e a Universidade Mackenzie. Tendência semelhante foi encontrada por Carlotto (2013, p. 269-72) no estudo do 
Laboratório Nacional de Luz Síncrotron, em que a autora aponta uma tendência centrípeta na formação dos pesquisadores, dirigindo-se às instituições mais centrais e legitimadas do campo científico, conforme desenrola-se o percurso de formação acadêmica. Nesse sentido, todos aqueles que fizeram a graduação em outras instituições justificam a mudança na busca por melhor infraestrutura, tecnologia mais atualizada e financiamento mais robusto.

Com exceção de uma jovem pesquisadora, todos os entrevistados realizaram alguma forma de iniciação científica durante o bacharelado, com ou sem bolsa concedida por agências de fomento. Aqueles que não fizeram, durante a graduação, estágio ou iniciação científica no laboratório em que pretendem realizar a pós-graduação, geralmente realizam um estágio informal, de duração média de seis meses, para conhecer a dinâmica de trabalho, os procedimentos adotados e as técnicas e instrumentos de uso mais rotineiro.

Outro dado relevante é que metade dos juniores não realizaram a etapa do mestrado, passando diretamente ao doutorado, proporção atípica no contexto brasileiro. Um dos jovens pesquisadores, cursando a modalidade de "doutorado direto" afirmou que a justificativa para pular a etapa anterior, por parte de sua orientadora - e uma das coordenadoras do centro de pesquisa - é que o tempo de mestrado seria curto demais para a realização de uma pesquisa consistente e original, além de uma suposta redução de bolsas dessa modalidade, por parte das agências de fomento, para a área das biológicas. Há poucos dados disponíveis para o desenvolvimento de uma explicação para esse fenômeno, pouco comum na trajetória acadêmica mais clássica, que tem como etapas a iniciação científica, o mestrado e o doutorado, mas aponta-se que essa é também uma característica marcante da formação desses jovens pesquisadores.

A inserção na pós-graduação deu-se da mesma maneira para todos os jovens pesquisadores, a partir do contato direto com a orientadora pretendida. Essa inserção, porém, só é possível quando há necessidade de um novo aluno no laboratório e vagas disponíveis na pós-graduação. Se essas condições forem satisfeitas, apresentam-se as linhas de pesquisa do laboratório ao aluno e o professor indica onde pretende alocálo. Nesse sentido, geralmente os estudantes não escolhem seus temas de investigação e inserem-se na linha de pesquisa que no momento necessite de mais pessoas.

De acordo com Delamont (2000, cap. 9), existiriam dois modos básicos de socialização no mundo acadêmico e em uma disciplina particular. No que o autor chama de "modo posicional", o estudante de doutorado torna-se parte de um grupo de pesquisa e trabalha em um tema - geralmente escolhido pelo orientador - que contribui para os esforços do grupo. O status e papel do jovem pesquisador é relativamente bem definido: ele é um aprendiz que ganha mais independência ao longo do processo de treinamento. A obtenção do título de doutor é visto como um dos passos na carreira; um pas- 
so importante, mas ainda assim apenas um passo. O suporte do grupo, especialmente dos pós-doutorandos, é fundamental, pois, no interior do grupo de pesquisa, as tarefas gerenciais e de busca de financiamento costumam estar concentradas nos coordenadores - que são também os orientadores - e, muitas vezes, sobra pouco tempo para a participação direta no processo de formação dos novos entrantes (cf. Delamont, 200০, cap. 9).

No "modo pessoal” de socialização, mais comum nas ciências sociais e humanidades, o estudante de doutorado trabalha de forma mais independente e seus interesses pessoais são decisivos na seleção do tema de pesquisa; além disso, é considerado normal que passe tempo considerável elaborando suas questões de pesquisa (cf. Delamont, 2000, cap. 9). Há grandes chances de ele ser tratado mais como colega do que como aprendiz e espera-se que a tese seja uma contribuição original para a disciplina, tornando-se a base de publicações posteriores. Segundo Hakala (2002, p. 7-8), esse modo de socialização, que reflete a tradição alemã, está diminuindo em muitos países, e o modo posicional, que reflete a tradição americana, vem se estabelecendo, inclusive nas ciências sociais.

Hackett (1990, p. 258-61) argumenta que a transformação em direção a um clima mais competitivo e comercializável na academia vem levando a uma especialização prematura entre os jovens pesquisadores e, como resultado, a uma redução de suas capacidades de realizar trabalhos independentes. Quando um coordenador escolhe um doutorando para seu projeto, suas responsabilidades para com o estudante podem colidir com suas responsabilidades junto ao projeto. A decisão pode ser entre treinar o estudante para tornar-se um pesquisador independente ou usar seu trabalho da forma mais eficiente-por exemplo, oferecer-lhe as tarefas de rotina, permitindo que os pesquisadores seniores tenham tempo para as tarefas mais complexas.

No centro de pesquisa estudado, o jovem pesquisador está claramente em uma posição subordinada em seu grupo de pesquisa mas, diferente do modelo posicional definido acima, ele é incluído em todas as fases do processo de pesquisa. Ainda que não escolha seu tema de investigação, ele aprende como desenhar um projeto, como realizar a compra de materiais, como prestar contas às agências de fomento, como produzir seus dados e como descrever os resultados de forma apropriada. Para os novos entrantes, parte importante da aprendizagem se dá com os colegas com mais tempo de trabalho e com os funcionários de cada laboratório. Como sinaliza uma das pesquisadoras juniores, esse processo de treinamento é feito geralmente "na oralidade".

É engraçado isso, o cientista é tão protocolar, né? Você acha que é tudo muito asséptico, que você pega um protocolo, segue ele à risca e as condições de temperatura e pressão (...). Não, é tudo muito na oralidade. O começo da biologia 
molecular, as coisas básicas como PCR, a gente aprendeu com colegas, um ensina o outro, que ensina o outro, que ensina o outro (pesquisadora júnior 2).

Esse aprendizado informal, oral e prático cria uma dinâmica própria no interior do laboratório, com pós-doutorandos ensinando doutorandos recém-chegados, mestrandos ensinando alunos da graduação, em uma estrutura fluida. Essa dinâmica de colaboração parece ser mais comum entre os jovens pesquisadores do que entre as pesquisadoras seniores, e costuma estar fundada em laços de amizade, entre pessoas que estudaram no Instituto de Biociências da USP, ou se conheceram nos seminários e outras atividades acadêmicas conjuntas. Um dos problemas desse tipo de organização do trabalho, baseado na competência adquirida pelos estudantes, é que se outros não se interessarem em utilizar a técnica aprendida e padronizada, esse conhecimento é perdido quando o primeiro estudante encerra sua participação no laboratório. Caso algum pesquisador deseje fazer uso dessa técnica posteriormente, ela precisará ser novamente aprendida.

Eu sempre tinha essa sensação, "estou sempre aqui inventando a roda”. Tudo que aprendia nesses laboratórios eu tinha que voltar aqui e estabelecer. Então, foi um doutorado um pouco desbravador, nesse sentido, porque foi penoso aprender as novas técnicas. E é uma coisa louca, supermutante, então a gente se esfalfava para estabelecer uma coisa e o projeto dos alunos não usava mais a tal técnica e ela se perdia (pesquisadora júnior 3).

Para o aprendizado de técnicas menos rotineiras, ou que ainda não são competência estabelecida no laboratório, é necessário que os estudantes recorram à literatura especializada e a colegas de outros grupos que já tenham mais domínio na técnica almejada. Para aquelas técnicas cujo uso é mais raro, são realizadas colaborações formais com laboratórios de outros departamentos ou instituições brasileiras ou, o mais comum, com instituições no exterior. No entanto, os juniores enfatizam menos as colaborações e mais o trabalho independente na busca de soluções como o fundamental no seu aprendizado. A autonomia é apresentada como uma habilidade fundamental para a realização da pesquisa na disciplina que escolheram.

A parte de biologia molecular eu aprendi na graduação. Novos métodos aprendi aqui [no laboratório da USP]. Métodos de análise estou aprendendo on-demand. É difícil, estou estudando estatística constantemente agora. Neuroanatomia, por exemplo, é algo que a gente viu como parte de uma disciplina da graduação, então estou aprendendo praticamente sozinho, consulto algumas pessoas, faço cursos, 
TrajetóRIAS E DivisÃo do trabalho No LAboratório DE GENÉTIGA HUMANA

online, presencial. É meio um walk alone, você vai andando e vai pegando o que você consegue, na medida em que você precisa. E, claro, a experiência nos dá um pouco de facilidade para aprender algumas coisas, né? (pesquisador júnior 4).

É possível afirmar que a formação dos juniores depende, em grande medida, de seus colegas de trabalho e de muito trabalho independente, muitas vezes regido pela dinâmica da "tentativa e erro". Está claro que os jovens pesquisadores nesse centro de pesquisa têm pouco poder para influenciar seu temas de pesquisa, mesmo que enfatizem que as pesquisadoras seniores se esforcem para levar seus desejos em consideração. E, até o momento, se eles têm ou não "liberdade acadêmica" não lhes parece uma grande preocupação.

\section{Divisão do trabalho Gientífico E GONSTituição de identidades}

A ênfase dos jovens pesquisadores - quando perguntados sobre seu processo de formação e seu cotidiano de trabalho - no aprendizado de novas técnicas de pesquisa e na manipulação de instrumentos, e a maneira como descreveram a relação com suas orientadoras de pesquisa, forneceram indícios importantes para analisar uma divisão de trabalho no interior dos sete laboratórios, entre pesquisadores seniores e juniores.

Contudo, é importante destacar que o laboratório não é uma entidade isolada e que a divisão do trabalho, seguindo as pistas de Bourdieu (2001a; 2001b), não pode ser entendida como um elemento de decisão racional dos membros dos sete grupos de pesquisa; ela precisa ser compreendida à luz de alguns elementos, tais como a complexidade técnica da pesquisa e a correlata especialização do trabalho, além de questões de âmbito institucional, tais como as restrições nas modalidades de contratação de pesquisadores e pessoal técnico e seu impacto na escolha dos temas de investigação e na formação dos jovens pesquisadores (cf. Ferreira, 2013, cap. 4).

$\mathrm{O}$ centro de pesquisa, por ser um grupo de pesquisa vinculado à universidade, tem características institucionais bem definidas, sendo uma delas o fato de seus participantes serem professores e funcionários concursados da USP, e bolsistas de diferentes instituições de fomento. A dificuldade de contratação de pesquisadores com outro vínculo que não via concurso público - realizado quando há disponibilidade de vaga e orçamento - é um dos fatores que contribuem para que os projetos dos jovens pesquisadores bolsistas sejam construídos de maneira a suprir determinada lacuna no grupo.

Mesmo que a pós-graduação seja um momento de formação para os estudantes, ela também possibilita, ainda que de modo às vezes precário, a constituição de grupos de pesquisa nas universidades brasileiras. Essa organização, ao olhar para os sete la- 
boratórios, tem como consequência uma divisão de trabalho que deixa a cargo dos jovens pesquisadores o domínio do método experimental. É, então, uma tarefa fundamental dos juniores manter os grupos tecnicamente atualizados, através de estágios no exterior ou em outros laboratórios do Brasil, e padronizar as técnicas após seu retorno, para estarem disponíveis como competência local de seu grupo.

Os jovens pesquisadores afirmam que é muito difícil o orientador acompanhar diretamente todos os desdobramentos da disciplina, em termos de métodos e técnicas de pesquisa, dedicando-se principalmente ao auxílio no que chamam de "questões mais amplas".

O orientador acaba ficando um pouco ausente disso [dos avanços da pesquisa], porque ele não está mais na bancada, né? Então ela tem o conhecimento de leitura, mas acaba não tendo o nosso conhecimento que é a prática, né? Já não tem mais o mesmo jogo de cintura de bancada, então tem detalhes de bancada que é mais fácil discutir entre a gente. Mas ideias de projetos, perguntar para ela se está bom ou não, o que acha de determinado artigo, para isso certamente é bom conversar (pesquisadora júnior 5 ). ${ }^{7}$

Esse tipo de organização - pesquisadoras seniores dedicadas às "questões mais amplas", à determinação de objetivos e à análise dos dados, e jovens pesquisadores dedicados ao trabalho "prático" - não é uma característica particular desses laboratórios que seguem o padrão dos centros de pesquisa visitados no exterior pelos estudantes. $\mathrm{O}$ aprendizado com os seniores, tanto nos laboratórios da USP quanto nos estágios no exterior, estaria centrado na análise de dados ou na inserção desses dados em uma perspectiva mais ampla da disciplina.

O que torna o indivíduo um pesquisador é a capacidade que ele desenvolve de interpretar aquilo que está vendo. Se você der para mim um resultado e der para a minha orientadora, ela vai conseguir enxergar muito mais do que eu. Porque, na verdade, em biologia molecular, em genética, quando você obtém um resultado no laboratório, ele nunca vai ser ruim, porque tudo é novo. Agora, a sua capacidade de associar aquilo ao sistema é que é uma coisa que vem com a vivência e é exatamente isso que o aluno vai aprendendo (pesquisadora júnior 6).

${ }_{7}$ Os pesquisadores seniores e juniores referem-se, a todo momento, à "bancada do laboratório", que corresponde à atividade de produção de dados, como coleta e análise de materiais, execução de protocolos, cuidados com as células e com os modelos animais. 
Nesse sentido, as citações em que os pesquisadores juniores relatam que suas orientadoras perderam parte das habilidades necessárias para "trabalhar na bancada" devem ser compreendidas à luz da noção de divisão do trabalho dentro dos grupos de investigação, em que pesquisadores seniores e juniores realizam atividades distintas na pesquisa. Diferentes tipos de atividades constroem identidades específicas e, no caso dos jovens pesquisadores, observa-se uma identidade associada à valorização do domínio da prática experimental. Ela é definida a partir dessa divisão do trabalho (e dessa oposição) em que os experimentos ficam a cargo dos juniores e a análise mais aprofundada a cargo dos seniores.

É importante destacar, no entanto, que a prática experimental não é exatamente rotineira, não é uma simples questão de aplicar ou reproduzir um experimento: ela exige um domínio dos instrumentos, reagentes e outros materiais disponíveis, que definirá o sucesso do experimento. O domínio da prática experimental pressupõe um conhecimento em estado prático que só pode ser incorporado através de um longo período de formação (cf. Bourdieu, 2001a, p. 81-6); implica, também, dominar quais questões podem ou não ser feitas na utilização de determinada técnica ou instrumento. De maneira geral, os estudantes se reconhecem nesse trabalho, valorizam-no e, assim, diferenciam-se de suas orientadoras, criando uma identidade própria.

Mas a contrapartida desse conhecimento hiperespecializado - que exige longo treinamento e dedicação - pode ser, justamente, um tempo menor disponível para a leitura e a análise dos dados e, ${ }^{\mathbf{8}}$ principalmente, uma menor facilidade de vincular os dados produzidos ao conjunto de questões mais gerais, ao estoque de conhecimento da disciplina de genética humana. Para esse trabalho, os estudantes contam com o auxílio de suas orientadoras e reconhecem nelas essa competência específica, diferente da deles, pois

não necessariamente um aluno sai do doutorado sabendo interpretar um resultado, tendo essa maturidade, mas a partir do momento em que ele quer ser pesquisador de verdade, aí ele passa a perceber a diferença de um chefe, quando ele pega um resultado e interpreta, em relação ao aluno (pesquisadora júnior 4).

Em outras palavras, os estudantes reconhecem que é necessário tempo - uma longa socialização na pesquisa - e certa maturidade para atingir o tipo e o nível de conhecimento que as pesquisadoras seniores detêm e que também são fundamentais para a produção, análise e apresentação de resultados relevantes. A divisão do trabalho apa-

8 Embora a quantidade de entrevistas não permita generalizações, destaca-se que a média de tempo de trabalho que os estudantes afirmaram passar na "bancada" é de ఛ०\%. 
rece como bem delimitada nos grupos e faz parte de uma dinâmica de produção do conhecimento na qual a predominância tecnológica acaba determinando os rumos da pesquisa, em que o domínio da prática experimental não é uma capacidade adquirida de uma vez por todas, considerando que as técnicas e equipamentos tornam-se obsoletos muito rapidamente.

Éum fenômeno bastante discutido na sociologia da ciência a emergência de "quase firmas" na universidade (cf. Etzkowitz, 1992, p. 33), para fazer referência aos casos em que o orientador se transforma em gerente, separa-se do exercício direto da pesquisa para concentrar-se nas tarefas de gerenciamento do grupo, como se ele fosse uma pequena empresa. Grande parte de seu tempo passa a ser dedicado à elaboração de propostas de financiamento, à escrita de artigos com os resultados de pesquisa da equipe, à seleção de novos integrantes, à resolução de problemas internos e à realização de tarefas administrativas.

Eu não vou mais para a bancada, não pego mais na pipeta, isso já deixou de existir. Quando você pega comprometimentos de cunho mais administrativo, não vai mais para a bancada. Me divirto com os resultados de bancada dos meus alunos, mas eu não vou mais (pesquisadora sênior 4).

Destaca-se que todas as pesquisadoras seniores ocupam ou ocuparam cargos administrativos, seja no próprio centro, seja na universidade, além de exercerem a atividade docente tanto na graduação quanto na pós-graduação e participarem, também, do serviço de aconselhamento genético. Com o tempo mais restrito para dedicar-se à pesquisa, as atividades geralmente destacadas nessa modalidade de trabalho são a escrita de artigos, a leitura e, principalmente, a orientação dos alunos. A articulação dessas diferentes atividades - funções administrativas, docência, pesquisa, orientação, prestação de serviços e busca de financiamento - ocupam espaços diferenciados na divisão do tempo das pesquisadoras, mas todas destacam-nas como cruciais no seu cotidiano de trabalho.

Foram criadas uma série de estratégias no interior dos grupos para dar conta das novas demandas da pesquisa em genética humana, estratégias essas que se desenrolam em um cenário institucional com limitações de ordem orçamentária e pouca flexibilidade na contratação de pesquisadores (sempre falando em termos relativos). A inserção de alunos de pós-graduação em linhas de pesquisa de acordo com as necessidades mais abrangentes do laboratório é uma estratégia importante face à dificuldade de contratar pessoal especializado, de acordo com as demandas mais específicas ou pontuais. Quando um jovem realiza sua pós-graduação em um dos laboratórios, ele está, de alguma maneira, vinculado ao padrão do trabalho intelectual autônomo. Então, ainda 
que muitas vezes não possa escolher seu tema de pesquisa, tem flexibilidade para definir a literatura com a qual trabalhará e as técnicas que elegerá. Ao mesmo tempo, sua experiência no laboratório evidencia as dificuldades para realizar um trabalho que seja articulado com o dos colegas e capaz de gerar resultados que tenham aplicação, quando se está no modelo do pesquisador autônomo. Ao identificar as dificuldades, alguns juniores defendem um outro modelo de organização, em que as coordenadoras dos laboratórios exerçam de forma mais ativa a figura de "chefes" e o controle e a definição da pesquisa seja feito de modo a desenhar um trabalho mais articulado, bem dividido, que possa produzir resultados padronizados e comparáveis. De forma esquemática pode-se caracterizar dois modelos: de um lado, aquele do pesquisador acadêmico independente e, de outro, o modelo contemporâneo das grandes equipes de pesquisa, especializadas e hierarquizadas. Nenhum dos dois modelos de pesquisa se realiza completamente no centro de pesquisa, havendo adaptações, oscilações e mistura entre eles. 9

De qualquer modo, um dos pontos fundamentais é que a formação de identidades acadêmicas está relacionada a mudanças estruturais, como as que afetam os padrões de financiamento e os formatos organizacionais. No entanto, também vem sendo mostrado que mudanças nos níveis macro não determinam como elas serão interpretadas e ativadas nem quais identidades vão emergir (cf. Collinson, 2003, p. 411-3). Em outras palavras, mudanças no nível macro não se traduzem automaticamente em certos tipos de identidades; ao contrário, identidades são construídas entre mudança e permanência, dependem das imagens da universidade e, não menos importante, dos valores, normas e práticas do campo científico, assim como das características locais.

Tal representação de si (cf. Goffman, 2013), para os jovens pesquisadores, inclui mostrar-se proficiente nas tarefas mais técnicas da pesquisa, e participar de numerosas atividades que não são estritamente vinculadas a sua tese, como a participação em numerosos cursos e seminários, no Brasil e no exterior. Ao engajar-se nessas atividades, os juniores sinalizam, para as pesquisadoras seniores, que seu comprometimento extrapola em muito as obrigações mais diretas de sua pesquisa. Isso é crucial, porque vai estabelecer sua reputação como alguém que detém competências técnicas acima da média, que são valiosas para o laboratório.

9 Neste artigo, foram priorizadas as estratégias e elementos mais comuns e gerais utilizados pelos sete laboratórios, tanto no que diz respeito à formação de novos entrantes, quanto à adaptação e produção de soluções face ao que consideram novos desafios da pesquisa em genética humana. Embora os laboratórios que compõem o centro de pesquisa possuam muitas características partilhadas, se mais detidamente examinados, revelam dinâmicas internas complexas, com subdivisões e distinções que não aparecem quando considerados a partir de dimensões mais amplas. Se, em um primeiro momento, o centro de pesquisa apareceu como o microcosmo a ser estudado, uma maior proximidade mostrou que é possível passar a uma escala ainda menor, e olhar para cada grupo também como um microcosmo passível de ser analisado sociologicamente. Por razões de espaço, as diferenças e especifidades de cada grupo não puderam ser aqui apresentadas, mas podem ser verificadas em Ferreira (2013, cap. 4). 
A divisão do trabalho pode também ser analisada considerando, como propõe Bourdieu (2001a, p. 74--7), o laboratório como um campo; apesar de definir-se por uma determinada posição na estrutura do campo disciplinar, o laboratório possui autonomia relativa e funciona como um espaço de posições que contribui para definir as estratégias dos agentes, a partir da distribuição de dois tipos de capital, científico e administrativo (cf. Bourdieu, 2001a, p. 110-6). Neste artigo, concentro-me em um tipo de relação - e de posições relativas - entre pesquisadores juniores e seniores, mas seria possível pensar em outras, como as disputas entre as próprias pesquisadoras seniores e entre os sete laboratórios.

Não é necessária uma análise pormenorizada para afirmar que as pesquisadoras seniores ocupam posição dominante em relação aos jovens pesquisadores. ${ }^{10}$ Para além do fato evidente de as primeiras já terem assegurado uma posição permanente na universidade que lhes permite fazer pesquisa, enquanto os segundos ainda sobrevivem de bolsas de pesquisa que têm prazo para terminar, o monopólio (relativo) da agenda de pesquisa do laboratório permite um grande controle do que é produzido e dos lucros simbólicos que são auferidos ao trabalho. Além disso, como os juniores não detêm nenhum capital administrativo ou capital científico temporal, eles dependem em muito do renome e dos contatos de suas orientadoras para conseguir bolsas de pesquisa e para completar sua formação em laboratórios no exterior. Nesse mesmo sentido, é possível afirmar que o capital científico acumulado por trabalhos de pesquisa de maior envergadura, que se utilizam de dados produzidos por mais de um orientando, é mais valorizado, no campo científico, que o trabalho hiperespecializado realizado pelos jovens pesquisadores.

\section{Considerações finais}

O artigo discutiu a divisão do trabalho científico entre pesquisadores seniores e juniores em um laboratório brasileiro de genética humana e médica em contexto de desenvolvimento da instrumentação e de crescentes custos da pesquisa. Foi realizado um breve panorama das transformações da subárea disciplinar em questão, centrando-se sobre como pesquisadores em um contexto específico, com características institucionais definidas e limitações de ordem orçamentária e organizacional, lidam com essas transformações. Por mais que haja mudanças e consequências da instrumentação, continua

10 Olhar para a relação entre pesquisadores seniores e juniores enquanto competição no interior do laboratório, entendido como um campo, é um processo de análise que destoa significativamente das falas que ressaltam o caráter de interdependência e ajuda mútua. Nesse sentido, o mais profícuo é compreender essas relações como sendo, ao mesmo tempo e inseparavelmente, de competição e de cooperação. 
difícil falar em tecnociência, considerando o forte componente disciplinar do centro estudado, no qual as questões de pesquisa estão profundamente ancoradas na matriz disciplinar, inseridas no cerne da agenda de pesquisa em genética humana e médica, embora contribuições de outras áreas sejam cada vez mais importantes para o bom andamento dos trabalhos. Outro indício se expressa no fato de a maior parte das pesquisas ser realizada no modelo clássico da tese de doutoramento. Ao mesmo tempo, é inegável a importância da tecnologia na pesquisa científica de matriz disciplinar, permitindo falar, talvez, em uma "nova disciplinaridade" (cf. Marcovich \& Shinn, 2012, p. $39-42)$.

A transição para novas modalidades de produção e análise de dados dependeu, predominantemente, da capacitação dos pesquisadores em centros de pesquisa na Europa e nos Estados Unidos, e essa atualização foi sempre realizada pelos jovens pesquisadores da instituição. Esse processo atualiza uma divisão de trabalho bem delimitada, que deixa aos jovens pesquisadores o domínio do método experimental e aos pesquisadores seniores a definição da agenda de pesquisa, auxílio na análise, busca de financiamento e obrigações de ordem burocrática. Tal dinâmica remete, em certa medida, a uma separação entre concepção e execução, mas seria necessário realizar uma pesquisa mais detalhada sobre o tema para compreender pormenorizadamente os meandros dessa separação.

Simultaneamente, pesquisadores seniores e juniores têm de lidar com a pressão por maior especialização no interior dos grupos de investigação, outra consequência das transformações da pesquisa, decorrentes da ampliação do espectro de instrumentos, métodos e técnicas. Para isso, foram criadas estratégias, em um cenário institucional com limitações de ordem orçamentária e pouca flexibilidade (em termos relativos), tais como incluir alunos de pós-graduação como membros mais ativos do grupo de pesquisa. No entanto, paralelamente às pressões e estímulos para a configuração de grupos de pesquisa no sentido forte do termo, com divisão do trabalho em que cada um faz partes de uma mesma pesquisa, tem-se, também, o modelo do padrão do trabalho intelectual autônomo, com cada pesquisador responsável por viabilizar uma pesquisa relativamente individual. Nenhum dos modelos se realiza completamente, sendo um achado desta pesquisa que há formas práticas de justaposição, compatibilização e complementaridade das características identificadas aos dois modelos.

Os grupos observados aparecem como o locus de produção do conhecimento científico em contraste com o imaginário de uma comunidade de especialistas que opera sobre a base individual e aderindo a uma normatividade compartilhada. ${ }^{\mathbf{1 1}}$ Mais ainda, 
é no nível do grupo de pesquisa que se produz o processo de socialização do pesquisador nas práticas de pesquisa e, a partir dessa socialização, define-se seu perfil enquanto tal. São esses processos de aprendizagem coletiva, baseados na interação do grupo, que sustentam o conhecimento tácito de tipo técnico-científico e de gestão da investigação. Esse conhecimento tácito pode ser visto, no caso do centro estudado, na formação das novas gerações, como descrita brevemente neste artigo, em que o aprendizado não se dá fundamentalmente a partir das aulas, dos livros, e mesmo da interação com as pesquisadoras seniores, mas sim com os colegas e funcionários mais antigos, e com a ida a centros de pesquisa no exterior.

O processo de formação cria e fortalece algumas disposições necessárias para o fazer científico e configura uma identidade própria que os juniores reivindicam e valorizam. O grande investimento de tempo e energia desde o início da graduação, a inclinação para fazer concessões quanto ao tema de pesquisa, e a capacidade de viabilizar a pesquisa de forma relativamente solitária - definindo com pouca supervisão qual o melhor caminho a trilhar e que métodos e técnicas utilizar - são requisitos exigidos desses jovens pesquisadores. Adicionalmente, a autonomia para buscar soluções e o interesse e disponibilidade para o acompanhamento e incorporação dos desenvolvimentos tecnológicos são também habilidades fundamentais para a realização da atividade na disciplina que escolheram.

Todos os juniores, sem exceção, reclamaram da não existência de um cargo de pesquisador nas universidades, e a maior parte deles parece identificar-se pouco com a figura do professor-pesquisador, tal como configurada no ensino superior brasileiro, pois acreditam que essa posição irá de alguma forma afastá-los da atividade de pesquisa que concebem como ideal. Ao mesmo tempo, é possível associar essa posição à identidade construída por eles, ligada ao domínio da técnica experimental e da figura de especialista em um conjunto reduzido e hiperespecializado de métodos e técnicas de pesquisa. Esse modelo de formação, fortemente ancorado na divisão do trabalho, coloca como questão se esses jovens conseguirão formar-se pesquisadores independentes, com as habilidades e competências, práticas e simbólicas, para tornarem-se sênior em alguma instituição de pesquisa.

Ainda que os planos para o futuro e o horizonte de possíveis desses jovens variem, um elemento comum a todos é a insegurança da condição temporária de realizar pesquisa mediante a concessão de bolsas, sem vínculo empregatício. Essa insegurança parece acentuar-se com os anos de treinamento e pesquisa, sendo os pós-doutorandos, notadamente aqueles que já estão em seu segundo ou terceiro pós-doutorado, os que mais sofrem com a instabilidade e os períodos sem nenhum tipo de remuneração, tendo, inclusive, dificuldade de identificarem-se e, principalmente, de serem identificados como adultos trabalhadores. 
Enquanto a formação consiste no primeiro estágio da reprodução de uma tradição de pesquisa em uma disciplina, para que essa tradição se mantenha é necessário que esses alunos encontrem posições que lhes permitam fazer pesquisa ou, em outras palavras, espaços para a reprodução institucional. Se as pesquisadoras seniores já têm seus postos de trabalho garantidos, estabilidade e condições mínimas para realizar pesquisa na universidade, os jovens pesquisadores possuem inserção necessariamente instável e transitória, e talvez seja essa a principal característica que permita tratálos como um grupo, a despeito de todas as diferenças individuais evidenciadas nas entrevistas. Um trabalho de maior fôlego para a compreensão das aspirações razoáveis e das trajetórias prováveis precisaria compreender uma análise objetiva do campo da genética humana e médica no Brasil, de modo a delimitar com mais precisão que postos estão, de fato, abertos a esses jovens pesquisadores, e que condições eles têm de tornarem-se pesquisadores seniores, no sentido atribuído pela divisão do trabalho científico no interior dos laboratórios.

Agradecimentos. A autora agradece o apoio da Capes para a realização da pesquisa de mestrado, da qual resultou este artigo.

\title{
Mariana Toledo Ferreira
}

Programa de Pós-Graduação em Sociologia,

Universidade de São Paulo, Brasil. mariana.toledo.ferreira@usp.br

\section{Trajectories and division of labor in a laboratory of human genetics}

\begin{abstract}
The article discusses the division of scientific labour among senior and junior researchers in a Brazilian research center for human and medical genetics. Starting with the contemporary debate on the progressive intertwining of science and technology - with progressive fusion of both, evoking notions such as technoscience - it is possible to verify, in this specific subarea, rising speed in data production that pressure scientists in different manners: through the rising cost of technological innovations and through the necessity for more complex methods of analysis. In this context I analyze issues concerning the specialization of scientific work, the separation between conception and execution as well as correlate changes in the formation of new researchers. The theoretical-methodological pressupposition is that scientific activity cannot be treated in a homogeneous way, and that there exist distinct configurations according to the disciplinary space, the institucional organization and local scientific tradition, understood as a historically rooted and socially and culturally contingent undertaking.
\end{abstract}

KEYwords $\bullet$ Division of scientific labor. Scientific training. Laboratory studies. Human genetics. Medical genetics. Technoscience. 


\section{REFERÊNGIAS BIBLIOGRÁFICAS}

Авгв-Ам, P. G. The discourse of physical power and biological knowledge in the 193 os: a reappraisal of the Rockefeller Foundation's 'policy' in molecular biology. Social Studies of Science, 12, 3, p. 341-82, 1982.

Battimore, G. Our genome unveilled. Nature, 4.09, p. 814,-6, 2001.

Ben-David, J. O papel do cientista na sociedade. São Paulo: Pioneira, 1974.

Bourdieu, P. Esquisse d'une théorie de la pratique. Paris: Éditions du Seuil, 2000. Science de la science et réflexivité. Paris: Raisons d'Agir, 2001 .

. Meditações pascalianas. Rio de Janeiro: Bertrand Brasil, 2001b.

Carlotto, M. C. Veredas da mudança na ciência brasileira: discurso, institucionalização e práticas no cenário contemporâneo. São Paulo: Scientiae Studia/34, 2013.

Collinson, J. A. Working at a marginal 'career': the case of UK social science contract researchers. Sociological Review, 51, 3, p. 4.05-22, 2003.

Cozzens, S. et al. (Org.). The research system in transition. Dordrecht: Kluwer Academic, 1990.

DAL Poz, M. Da dupla à tripla hélice: o projeto genoma xylella. 2002. Dissertação (Mestrado em Política Científica e Tecnológica). Campinas: Instituto de Geociências, Universidade Estadual de Campinas.

Delamont, S. et al. The doctoral experience: success and failure in graduate school. London/New York: Falmer Press, 2000.

Dreger, A. D. Metaphors of morality in the human genome project. In: SloAn, P. R. (Org.). Controlling our destinies: historical, philosophical, ethical, and theological perspectives on the human genome project. Indiana: University of Notre Dame Press, 2000. p. 155-84.

Elzinga, A. The new production of particularism in models relating to research policy. A critique of mode 2 and triple helix, paper prepared for the Nobel Symposium Science and Industry in the 20 Century, Stockholm, 21-23 Nov. 2002.

Етzкожгтz, H. Individual investigators and their research groups. Minerva, 3, p. 28-50, 1992.

FAPESP. Um novo paradigma para a organização da pesquisa: centros de pesquisa, inovação e difusão terão a missão de aproximar a ciência da sociedade. Pesquisa Fapesp, 57, p. 8-19, 2000.

Ferreira, M. T. A institucionalização da pesquisa em genética no Brasil e seus pesquisadores: um estudo de caso do Centro de Estudos do Genoma Humano da USP. Dissertação (Mestrado em Sociologia). São Paulo: Faculdade de Filosofia, Letras e Ciências Humanas, Universidade de São Paulo, 2013.

Foucault, M. História da Sexualidade I: a vontade de saber. Rio de Janeiro: Graal, 1979. . Power/knowledge: selected interviews and other writings, 1972-1977. New York: Pantheon Books, 1980. . Microfísica do poder. Rio de Janeiro: Graal, 1988.

Freeman, C. The "National System of Innovation" in historical perspective. Cambridge Journal of Economics, 19, p. 5-24, 1995 .

Garcia, J. L. \& Martins, H. O ethos da ciência e suas transformações contemporâneas, com especial atenção à biotecnologia. Scientiae Studia, 7, 1, p. 83-104, 2009.

Garcia, S. G. \& CARLotto, M. C. Institutional specificity and organizational change: a case of university social engagement in Brazil. In: Pinheiro, R. et al. (Org.). Universities and regional development: a critical assessment of tensions and contradictions. New York: Routledge, 2012. p. 124, 4, 0.

Giввоns, M. et al. The new production of knowledge: the dynamics of science and research in contemporary societies. London: Sage, 1994.

Gingras, Y. Physics and the rise o scientific research in Canada. Montreal: McGill-Queen's University Press, 1991.

Goffman, E. A representação do eu na vida cotidiana. Petrópolis: Vozes, 2013.

HACKETT, E. J. Science as a vocation in the 1990s: the changing organizational culture of academic science. The Journal of Higher Education, 61, 3, p. 241-79, 1990. 


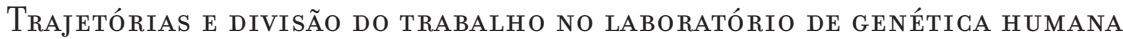

Hackett, E. J. et al. (Org.). The handbook of science and technology studies. Cambridge: The MIT Press, 2008.

HAKALA, J. Junior Researchers in the 'postacademic' university: changing values, motivation and career paths, paper to EASST Conference Responsibility under Uncertainty: Science, Technology and Accountability, York UK, July 31-August 3, 2002.

Henriques, F. Idéias, redes e dinâmica política: a construção da agenda da inovação na Fapesp. Dissertação (Mestrado em Sociologia). São Paulo: Faculdade de Filosofia, Letras e Ciências Humanas, Universidade de São Paulo, 2010.

KaY, L. E. The molecular vision of life: Caltech, the Rockefeller Foundation and the new biology. New York: Oxford University Press, 1993.

Kreimer, P. Ciencia y periferia: nacimiento, muerte y resurrección de la biología molecular en la Argentina. Buenos Aires: Eudeba, 2010.

LAGEY, H. Reflections on science and technoscience. Scientiae studia, 10, n. spe, p. 103-28, 2012.

LENoIr, T. Instituindo a ciência: a produção cultural das disciplinas científicas. São Leopoldo: Unisinos, 2003.

Lock, M. Biomedical technologies, cultural horizons and contested boundaries. In: HACKETT, E. J. et al. (Org.). The handbook of science and technology studies. Cambridge: MIT Press, 2008. p. 875-900.

Lock, M. et. al. (Org.). Living and working with the new medical technologies. Cambridge: Cambridge University Press, 2000.

Mackenzie, A. Bringing sequences to life: how bioinformatics corporealizaes sequences data. New Genetics and Society, 22, 3, p. 315-32, 2003.

Marcovich, A. \& Shinn, T. Padrões sociointelectuais da pesquisa em nanoescala: laureados com o Prêmio Feynman de Nanotecnologia, 1993-2007. Scientia Studiae, 7, 1, p. 11-39, 2009.

Regimes of science production and diffusion: towards a transverse organization of knowledge. Scientae Studia, 10, n. spe, p. 33-64, 2012.

NeLson, R. National innovation systems: a comparative analysis. Oxford: Oxford University Press, 1993.

Osada, N. M. O processo de biomedicalização no Brasil: estudo da prática científica em pesquisas sobre doenças genéticas. Tese (Doutorado em Política Científica e Tecnológica). Campinas: Instituto de Geociências, Unicamp, 2012.

Pinheiro, R. et al. (Org.). Universities and regional development: a critical assessment of tensions and contradictions. New York: Routledge, 2012.

RaBinow, P. Making PCR: a story of biotechnology. Chicago: University of Chicago Press, 1996.

Rheinberger, H. G. Beyond nature and culture: modes of reasoning in the age of molecular biology and medicine. In: Lock, M. et. al. (Org.). Living and working with the new medical technologies. Cambridge: Cambridge University Press, 2000. p. 19-30.

Shinn, T. Hiérarchies des chercheurs et formes des recherches. Actes de la Recherche en Sciences Sociales, 74 , p. 2-22, 1988.

Shinn, T. \& Ragouet, P. Controvérsias sobre a ciência: por uma sociologia transversalista da atividade científica. São Paulo: Associação Filosófica Scientiae Studia/Editora 34, 2008.

Sloan, P. R. Completing the tree of Descartes. In: Sloan, P. R. (Org.). Controlling our destinies: historical, philosophical, ethical, and theological perspectives on the human genome project. Indiana: University of Notre Dame Press, 2000. p. 1-26.

Sloan, P. R. (Org.). Controlling our destinies: historical, philosophical, ethical, and theological perspectives on the human genome project. Indiana: University of Notre Dame Press, 2000.

Silva, R. G. L. \& DA Costa, M. C. Instrumentos de política de ciência e tecnologia em genômica do Estado de São Paulo. Revista de Políticas Públicas, 16, 2, p. 493-501, 2012.

WiLkie, T. Projeto Genoma Humano: um conhecimento perigoso. Rio de Janeiro: Jorge Zahar, 1994.

Ziman, J. M. What is happening to science? In: Cozzens, S. et al. (Org.). The research system in transition. Dordrecht: Kluwer Academic, 1990. p. 23-33. 